How to cite this article:

Nadarajan, T., Mohamad Khairi, H. O., \& Noor Banu, M. N. (2020). Using forum theatre to develop various levels of thinking skills among moral education students in secondary school. Malaysian Journal of Learning and Instruction, 17(2), 167-194. https://doi.org/10.32890/mjli2020.17.2.6

\title{
USING FORUM THEATRE TO DEVELOP VARIOUS LEVELS OF THINKING SKILLS AMONG MORAL EDUCATION STUDENTS IN SECONDARY SCHOOL
}

\author{
${ }^{1}$ Nadarajan Thambu, ${ }^{2}$ Mohamad Khairi Haji Othman \& ${ }^{3}$ Noor \\ Banu Mahadir Naidu \\ ${ }^{1 \& 3}$ Faculty of Human Science, \\ Universiti Pendidikan Sultan Idris, Malaysia. \\ ${ }^{2}$ School of Education and Modern Languages, \\ Universiti Utara Malaysia, Malaysia. \\ 'Corresponding author: nada@fsk.upsi.edu.my
}

Received: 22/1/2019 Revised: 20/5/2020 Accepted: 12/6/2020 Published: 31/7/2020

\begin{abstract}
Purpose - The power of forum theatre in education and various other fields is well known by educators. However, the use of forum theatre in Malaysia, particularly in the field of moral education, is still limited. At the same time, the development of thinking skills is one of the aims of the Malaysian moral education curriculum. Therefore, this study examined the use of forum theatre as a pedagogical tool in developing various levels of thinking skills among moral education students.

Method - The study adopted a qualitative research design and was underpinned by Bloom's revised taxonomy as the theoretical and analytical framework. A total of 14 moral education students participated in this study. Data were collected qualitatively using classroom observations, interviews, and journal writing. Thematic analysis was utilized to analyse and present the findings.
\end{abstract}

Findings - The findings revealed that various theatrical activities that underpinned the four elements of forum theatre: (i) writing a 
script, (ii) delivering a dialogue in an anti-model play, (iii) discussion and decision-making in a forum session, and (iv) improvisation in an intervention play, show the development of students' thinking skills at the level of analysing, evaluating and creating. Therefore, this study suggests that forum theatre can be used in moral education pedagogy to enhance higher order thinking skills.

Significance - Meaningful instructional pedagogy must inspire thinking skills to foster creativity and innovation among students. This is considered an important skill in $21^{\text {st }}$ century learning. Hence, these findings are beneficial for teachers, lecturers, parents and instructional designers who wish to plan and implement suitable teaching methods such as forum theatre to empower and improve students' thinking skill levels.

Keywords: Forum theatre, thinking skill levels, higher order thinking skills (HOTS), technique, moral education, pedagogy.

\section{INTRODUCTION}

Thinking skills are integrated through pedagogical and curricular aspects in all school across all subjects, including moral education (Norhezan, Nor Hashimah, \& Ainon, 2017; Rajendran, 2017). Individual moral action depends on the capabilities of reasoning and decision making, as morality is basically a "law of reasoning" (Kohlberg, 1984). Therefore, teaching practices, pedagogy and teaching strategies are important components in ensuring that the subject content (Aravind, Gamboa, \& Lim, 2019; Hanita \& Norzaini, 2018) and moral content delivered by teachers in the classroom stimulate students' thinking skills (Suppiah, Barathy, \& Sandra, 2017). According to Varutharaju and Ratnavadivel (2014), teachers as facilitators play a crucial role in engaging learners with a higher order thinking modality and in making their thinking visible by utilizing metacognition and self-regulation abilities (Kaviza, 2020; Mohd Zaidi, Ahmad Zabidi, \& Rafiza, 2020).

Moral education programmes in Malaysia focus on nurturing the spirituality, moral thinking and moral strength of students through appreciating and practicing the values of Malaysian society (Ministry of Education Malaysia, 2000). The programmes also aim to produce individuals who have a moral and social obligation in their thinking, decisions and actions (Abdul Pabil, Barathi, \& Vijayaletcumy, 
2019). Decisions and individual moral actions of students depend on thinking and reasoning capabilities in situations of moral conflict (Colby \& Kohlberg, 2011). Moral reasoning can also be defined as the process by an individual to reach an informed decision about what should be done in a moral dilemma.

Many studies have shown a relationship between aspects of moral reasoning, moral thinking and moral behaviour (Colby \& Kohlberg, 2011). Studies in Malaysia have shown that moral reasoning among Form Four students in some schools can be enhanced through the use of moral dilemmas (Jeevajothi, 1997), Vignet dilemmas (Chang, 2007) and effective teaching pedagogy (Nadarajan, Harun Joko Prayitno, \& Gamal Abdul Nasir, 2020). Mohd Zailani (2012) showed that trust and faith, intrinsic and extrinsic dimensions in terms of Islamic inclination, have a significant impact on the moral reasoning of religious school students in particular.

According to Dewey (1909), teaching is more effective when it uses real events to address the problems of real people in their relationships with the world. A review by Balakrishnan $(2011,2019)$ found that "real-life dilemmas" used in teaching moral education in school help student deal with real moral conflicts in their own daily lives. This implies that developing as a moral agent involves moral reasoning or judgments when making decisions on what ought to be done and how to act upon them (Norzihani, \& Nur Surayyah Madhubala, 2015).

A more competent and creative pedagogical form is needed to stimulate students to think. This creative kind of pedagogy needs to be embedded in the form of teaching techniques that can nurture students' thinking skills to higher levels. Forum theatre introduced by Boal (2008), is a technique rooted in real moral conflicts experienced by students in their lives. Forum theatre could provide opportunities for students to be involved in thinking processes in the classroom (Nadarajan, 2019). It is an interactive teaching and learning technique that requires students to actively participate in developing a script, memorizing, engaging in forums, acting, and expressing ideas.

Forum theatre provides the conditions in which both students and teachers are actively, critically and reflectively engaged in thinking and knowledge-making (Nadarajan, 2019). This interactive teaching 
technique can provide students with opportunities to engage cognitively, examine critical conflicts of morality and seek solutions to problems.

\section{Levels of Thinking Skills}

Thinking skills involve the ability to apply knowledge, skills and values (Anderson \& Krathwohl, 2001) in reasoning and reflecting to solve problems, make decisions, innovate and create (Ministry of Education Malaysia, 2013). A framework that is still considered very useful among educators is Bloom's Taxonomy (Bloom, 1956), which qualitatively translated the thought process and classified the levels of thinking into six complex cognitive stages (Tajularipin, Vickneswary, Diwiyah, Raidah, \& Suzieleez Syrene, 2017). The six stages or levels of thought are: knowledge, understanding, application, analysis, synthesis and evaluation (Bloom, 1956). Bloom's taxonomy was later revised and modified by his pupil Lorin Anderson (Anderson \& Krathwohl, 2001) in accordance with current requirements to be more relevant to students and teachers. Changes were made in the arrangement and labelling of each level using verbs rather than nouns to reflect the thinking process. Rankings in the Anderson and Krathwohl (2001) Taxonomy begin with remembering, followed by understanding, applying, analysing, evaluating, and creating. Ashton (1988) classified the analysing, evaluating, and creating stages as higher order thinking skills (HOTS).

In the Anderson and Krathwohl (2001) Taxonomy, analysing skills require students to divide or convert something large into smaller components. Students will brainstorm concepts, information and ideas, breaking them down to simple and concise components. Evaluation skills involve the ability to make judgments or justifications based on criteria and standards through examination and critique. Students must justify, assess, recommend, determine, judge, suggest and select. Meanwhile, creating skills are the skills to put together different elements to form a coherent (integrated) or fully functional system. This includes reorganizing different elements into a new pattern or structure through generation, planning or production. Students must create, design, plan, create, construct and imagine. 


\section{Forum Theatre}

Forum is derived from the Greek term meaning an open discussion field, while theatre refers to a genre of art or a form of communication. This interactive theatre form was developed by Augusto Boal of Brazil (Babbage, 2004). In forum theatre, the actors will dramatize social problems or "oppression" that occurs in the community for the community's views (Babbage, 2004). The goal of forum theatre is to provide the opportunity for the actors and the audience to express publicly and receive views on the issues presented (Boal, 2008). A forum theatre will end with an unresolved problem. Then, the audience (spectators) is given the opportunity to explore solutions to the above problems through play. Forum theatre has been widely used in school to address issues such as caring moral reasoning (Letchumie Devi \& Nadarajan, 2020), environmental value, racism, sexual prejudice, violence and bullying (Schonmann, 2005).

Teaching and facilitation of moral education in school should be based on stimulus materials such as situations of moral dilemma (Colby \& Kohlberg, 2011). In forum theatre, a situation of moral dilemma is presented to stimulate students' thinking and ideas to solve the dilemma. This stimulating material (anti-model acting) is potentially capable of developing critical and creative individual moral thinking. Students would then solve problems or moral dilemmas that are revealed through the intervention play. In this context, students would use high-level thinking skills such as application, analysing, evaluation and creation. The whole technique of forum theatre is also based on the concept of active learning (Nadarajan, Harun Joko Prayitno, \& Gamal Abdul Nasir, 2020).

The four steps involved in forum theatre techniques are (a) develop a script, (b) anti-model play, (c) forum, and (d) intervention play (Boal, 2008). The following is a discussion of the four steps, with a detailed description of student participation in each step, as applied in this study.

\section{(a) Develop a Script}

In this step, students are asked to develop a script based on their own experiences related to the lesson or topic being taught in moral education. The focus would be "moral conflict," and the scenario 
could be almost any topic that resonated with a moral dilemma (Boal, 2008; McClimens \& Scott, 2007). In this study, the participants collaborated in developing a script about their shared challenges. Participants wrote five scripts to demonstrate a moral dilemma and the problems causing conflict in their daily lives: Script A (conflicts when executing a "group study" among classmates; Unit 1.4Responsible), Script B (conflict between neighbours/medical doctor and a sick neighbour; Unit 1.9-Affection), Script C (family conflict in maintaining the children's marital customs; Unit 2.3-Traditions and Heritage), Script D (husband-wife conflicts; Unit 5.2-Women's Rights); and Script E (conflict in business between two tailors; Unit 6.2-Tolerance). The units shown in brackets refer to teaching units from textbooks.

\section{(b) Anti-model Play}

After composing the script, students have to act out the developed script for class viewing. Their moral conflict scene is performed as an "anti-model" play. Boal (2008) created the term "anti-model" play because it is not the model we would want to follow, but the model we need to change. It is compulsory for the scene (anti-model play) performed to display moral conflict or pressure situations in which a character being victimized or in a dilemma fails to overcome the persecution. The objective of this step is to stimulate the audience to act or intervene in the problem they see.

\section{(c) Forum}

In forum theatre, the facilitator of the action is the Joker. The Joker discusses with the audience the problems that appear in the presentation, and possible solutions are proposed to overcome the above problems. The Joker then asks the audience to figure out the right solution or idea that can be implemented to resolve the conflict experienced by the oppressed characters in the play. Discussion, improvisation and audience participation are known as the "forum" in forum theatre (Gourd \& Gourd, 2011).

\section{(d) Intervention Play}

During intervention sessions, the anti-model play is presented for a second time. This time, the audience members have the opportunity 
to intervene and bring the play to a different and improved end. An audience member takes the place of an actor to demonstrate his or her ideas for resolving a problem. They can do so by taking on the role of a specified victimized character from the anti-model play. The Joker makes sure that the solutions are explored adequately by the audience members and that they are to some extent possible in real life (Boal, 2008). Through the intervention play, the conflict highlighted (anti-model play) is resolved in a moral manner.

\section{Forum Theatre for Developing Thinking Skills?}

According to Fisher (2003) the main objective of a theatre programme such as forum theatre in education is to encourage students to think. One educational function is to teach students about why and how to think. Therefore, theatre pedagogy in education should be made a component of the thinking curriculum. The theatre programme in education is based on student-centred pedagogy and the programme focuses on "student thought." Fisher (2003) posited the following:

The development of our minds is part of what it means to be educated, because it is part of what it means to be human. According to this view, the key function of education is to teach children to think critically, creatively, and effectively. (p. 6)

According to Narvaez and Lapsley (2008), the moral domain should be trained to ensure skill development. In the context of this study, forum theatre teaches actors to feel like other people, think as others think of them, and act like other people through acting. Moral behaviour can be formed by familiarizing students to feel the right thing and think of the right thing at the right time and towards the appropriate person (Kristjansson, 2009). All these skills are trained through forum theatre activities such as anti-model plays, forum sessions and intervention plays. Through the intervention of acting, forum theatre provides an opportunity for participants to build thinking, feeling, and reflection through creative problem solving. Boal (2008) argued that real and tangible action in intervention plays stimulate thinking and learning.

Forum theatre can also provide skills in making moral judgments, and problem solving based on morality, as stated in the moral 
education syllabus (Ministry of Education Malaysia, 2000). Forum theatre has shown that individuals who possess moral judgment skills have the ability to analyse when dealing with conflict situations and to respond with appropriate decisions and actions. According to Boal (2008), a reasonable decision-making skill in real life would produce citizens who are critical thinkers. Levy (1977) stated that the rationale behind the full focus of theatre audiences is that they can think, and by over thinking they would learn. Furthermore, in response to a moral dilemma, the highest level of student thinking and reasoning can be elicited.

\section{METHOD}

\section{Research Objectives}

The study aimed to investigate the use of forum theatre as an instructional tool in developing various levels of thinking skills among moral education students by answering the following research question: How does forum theatre develop various levels of thinking skills?

\section{Participants}

A purposive approach to sampling was undertaken (Richards $\&$ Morse, 2007) to select the participants. Voluntary consent and parental consent letters were distributed to the students and their parents. Only students who agreed, and who were allowed by their parents, were selected to participate in the study. A total of 14 Form Four students (seven male and seven female) from two urban schools were selected. All participants were aged 16, of Indian or Chinese ethnicity, and from a science stream moral education class (see Tables 1 and 2). Each school created a focus group consisting of seven students per group. Permission to conduct the research was obtained from the Educational Planning and Research Division (EPRD), Ministry of Education Malaysia, the State Education Department, and the District Education Office. 
Table 1

Profile of Participants (School A)

\begin{tabular}{llllll}
\hline Participants & Ethnicity & Gender & $\begin{array}{l}\text { Area of } \\
\text { Residence }\end{array}$ & $\begin{array}{l}\text { PMR } \\
\text { Results }\end{array}$ & $\begin{array}{l}\text { Parent's } \\
\text { Occupation }\end{array}$ \\
\hline Respondent 1 & Chinese & Female & Urban & 6A & Teacher \\
Respondent 2 & Indian & Male & Rural & 5A & Factory worker \\
Respondent 3 & Chinese & Female & Urban & 6A & Shop keeper \\
Respondent 4 & Chinese & Male & Urban & 5A & Self employed \\
Respondent 5 & Indian & Male & Suburban & 5A & Skilled worker \\
Respondent 6 & Indian & Female & Rural & 5A & Factory worker \\
Respondent 7 & Indian & Female & Suburban & 6A & Lorry Driver \\
\hline
\end{tabular}

Note: PMR Results $=$ Performance on the Lower Secondary Assessment, a national assessment taken by Form 3 students at the end of 3 years of lower secondary education. $6 \mathrm{~A}=$ Excellent; $3 \mathrm{~A}-5 \mathrm{~A}=\mathrm{Above}$ average; Below $3 \mathrm{~A}=$ Average.

Table 2

Profile of Participants (School B)

\begin{tabular}{llllll}
\hline Participants & Ethnicity & Gender & $\begin{array}{l}\text { Area of } \\
\text { Residence }\end{array}$ & $\begin{array}{l}\text { PMR } \\
\text { Results }\end{array}$ & $\begin{array}{l}\text { Parent's } \\
\text { Occupation }\end{array}$ \\
\hline Respondent 1 & Chinese & Male & Urban & 5A & Medical Doctor \\
Respondent 2 & Indian & Female & Urban & 6A & Teacher \\
Respondent 3 & Chinese & Female & Suburban & 6A & Self employed \\
Respondent 4 & Chinese & Male & Urban & 5A & Skilled worker \\
Respondent 5 & Indian & Male & Rural & 5A & School Clerk \\
Respondent 6 & Indian & Female & Suburban & 6A & Factory worker \\
Respondent 7 & Chinese & Female & Urban & 5A & Bank Officer \\
\hline
\end{tabular}

Note: PMR Results $=$ Performance on the Lower Secondary Assessment, a national assessment taken by Form 3 students at the end of 3 years of lower secondary education. $6 \mathrm{~A}=$ Excellent; $3 \mathrm{~A}-5 \mathrm{~A}=\mathrm{Above}$ average; Below $3 \mathrm{~A}=$ Average. 


\section{Data Collection}

The data sources used for this study comprised student interviews, students' reflective writings in journal entries, and observation notes. Participants were interviewed at the end of the moral education class session. Guided semi-structured interview questions were used in guiding the reflective thinking process, in particular reflecting on specific learning activities involved in the forum theatre. Apart from that, at the end of the lesson in every session, participants wrote a journal of reflections and comments regarding their involvement in the forum theatre activities. Students' journals were used to analyse their critical thinking, reflective thinking, judgments and involvement in the forum theatre. Another source of data was the classroom observation protocol, which was used to investigate students' thinking processes, decision-making and reasoning on particular issues.

The instruments for this study were developed from literature reviews and technical literature from related sources. The items on the three instruments (classroom observation, interviews and journals) were validated by experts. Bahasa Melayu, the national language, was used in the forum theatre activities, journal entries as well as interviews.

\section{Data Analysis}

Thematic techniques (Braun \& Clarke, 2006) were used for data analysis. A total of 20 reflective writing journals from the students and two reflective writing journals from the teacher (observer) were collected at the end of week 10. In addition, 10 transcribed interviews and 10 sets of observation notes were also collected for analysis. The researchers focused on analysing each answer from the data sources for thoughts pertaining to analysing, evaluating and creating. These 42 written reflections (transcripts) were then studied and analysed to determine the emerging themes. The data were analysed using Nvivo version 11 . With the thematic techniques, the coding scheme was initially guided by the research questions, which provided the main themes and key coding. Coding was created by creating a Node (database) with the Nvivo software.

Two phases of coding (open coding and axial coding) were used in the process of identifying correlates of data in an idea, category and 
theme (Braun \& Clarke, 2006). Each coding and statement obtained from the transcript source was then verified. The major categories of the coding were predetermined from the three attributes of thinking levels: analysing, evaluating and creating. Nevertheless, small codes (or themes) were generated from the above major categories. Triangulation was used for cross-checking and verification of the data (Passi \& Mishra, 2002). The findings were categorized according to several themes.

\section{RESULTS}

The aim of this study was to gain insights on how the various theatrical activities that underpinned the four elements of forum theatre-(i) developing script, (ii) anti-model play, (iii) forum, and (iv) intervention play - can develop moral education students' thinking skill levels. Several pertinent themes emerged from the data. To answer the research question of how forum theatre develops various levels of thinking skills, the findings are reported according to several themes (see Figure 1).

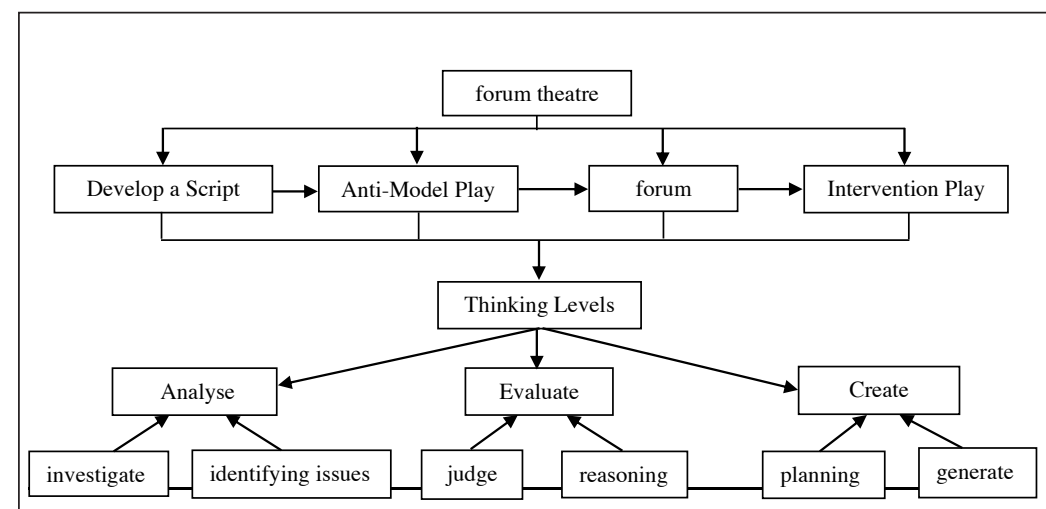

Figure 1. Students' thinking levels.

\section{Theme 1: Analysing Level}

Activities such as writing scripts, anti-model plays and forum sessions in forum theatre can be used to trigger various thinking levels among 
participants. Features such as interpreting situations rationally in developing scripts, investigating, thinking, and identifying issues in anti-model plays and forum sessions can develop thinking skills among the participants, especially at the level of analysis. This level generated two subthemes: identifying issues and investigating. The following is an analysis of the findings of the two subthemes that made up Theme 1 .

\section{Identifying issues}

The results of the interviews showed that the participants could identify the problems given by simplifying complex situations to a narrow focus. Participants were able to identify the issues presented in all anti-model play on the issues raised, the importance of the issue, and the impact of the issue to the self and the community if not resolved immediately. The participants would also discuss the traits that must exist in one's character and categorize them as a good character (antagonist) or evil character (protagonist).

This is illustrated in the following interviews:

Researcher: How do you analyse the anti-model play? Participant 6:

After watching the anti-model play session (script C), we will persuade the problem that is displayed based on the characters. Usually we will analyse the character of a person to determine a character as a good character or evil character. In this way, we can determine the issues, problems, or conflicts presented through this anti-model play. Furthermore, we have to think critically to identify the person's character.

[school B/int/19.5.18]

Researcher: What is the issue shown in script C? Participant 1:

In script $\mathrm{C}$ (anti-model play) is a child issue that violates the customs and heritage of their ancestors. We have separated the issues, from the moral, family customs and traditions. We can foresee that if this issue is not 
resolved, then it will create disorganized family and society because there is no custom and tradition in the family.

[school A/int/19.5.18]

In addition, the journal entries of the participants also showed the importance of identifying issues as the basis of the analysis process. They used the method of exploring to determine the cause of a conflict and to determine the inner and outer character of a character acting in an anti-model play and intervention play, as shown in the following journal entries:

Today I was playing Sarah's role in intervention play. After identifying the traits of Sarah's character in script C (anti-model acting), I find that Sarah's character is not a woman who adheres to customs and eastern values. Sarah wants to marry Farhan without the parents' consent. As a result, in the intervention session, when I acted as Sarah, I was able to shape Sarah's character to women who are concerned with the customs and heritage of the family tradition. I can show Sarah's character differences in an anti-model play and intervention play.

[school A/jur/R4/20.5.18]

Today I was involved in a group discussion before creating an intervention play. I noticed that my group succeeds in comparing and separating the negative traits inherent in Ikhwan's character as a warm-hearted husband with no compassion and a high ego (script D). I separate all the negative attributes inherent in Ikhwan's character and replace it with a positive nature. In the intervention play of script $\mathrm{D}$, I can produce different Ikhwan characters from the anti-model play. Ikhwan's character is now better as a husband who loves his wife and understands the wishes of his wife.

[school B/jur/R1/14.4.18]

The observation results [school A/obs/Bnu/23.5.18] also showed that the participants were able to analyse, compare, contrast, evaluate and predict the issues presented in the anti-model play, whether 
the issue was relevant to individuals, families, school children or communities. Subsequently, they could also predict the solution to the issues featured in the anti-model play by giving some reasonable suggestions. All the ideas relating to the solution were also presented in the forum session. These ideas were then tested for effectiveness in the intervention play. One observer regarded intervention play sessions in forum theatre as an experimental laboratory of various alternative solutions submitted by the participants.

\section{Investigate}

The interviews also showed that the participants investigated the theme previously provided before authoring the script for the antimodel play. Participants used prior knowledge about the theme given and investigated the importance of the theme in human life. Investigations also continued to determine the importance and relevance of the theme in participants' daily lives. Issues and conflicts related to the theme were played in the anti-model play. This is shown in the following interviews:

Researcher: How do you define the appropriate situation for a given theme? Participant 3:

Our teacher gives a clear theme that is to keep the traditions. Our group has made a little investigation or research on the purpose of this theme. The investigation results show that our task is to create situations that show characters that do not respect our ancestral customs. We have written scripts based on this investigation and played them in the anti-model play.

[school B/int/4.4.18]

Researcher: How can you describe the solution in intervention play? Participant 6:

We first analyzed the problem shown in the anti-model play... be sure to characterize the character that should be changed. We should also assess whether the act of Esah's character is moral duty or not. We find there is no moral values in Esah's character... then we use ideas... Now Esah should change a character from bad to good. 
So Esah starts to do the good things such as organize the workshop to teach the villagers how to sew clothes ... This idea we test in the intervention play.

[school A/int/4.4.18]

In addition, participants' journal entries also pointed out that they first investigated the issues raised in the anti-model play before they determined the issues and solutions to the problem. The participants investigated the cause of the conflict and sought solutions to the conflict, as seen in the following journal entries:

Today I was involved in writing scripts. To do the antimodel script (script E), I used to investigate before looking for issues or conflicts that existed. I find the conflict in this anti-model play is disrespectful friends who make the same business, for example a business as a tailor. This causes both parties to always fight and disagree. When I acted as Esah in intervention play, I became a character who likes to help the villagers who want to be tailors.

[school B/jur/R6/5.4.18]

Today the forum sessions gave me the opportunity to see and investigate the issues given by a Joker. I noticed that the Joker provided a conflict that was featured in the anti-model play. We have to think high-level as well to compose intervention scripts as it needs to analyse and investigate some things before writing a good script.

[school A/jur/R6/5.4.18]

Observation notes [school B/obs/Ban/12.4.18] also showed that since the assignment of scripts was given, participants made many investigations to find situations, issues or conflicts for the anti-model play and alternative solutions to be used for the intervention play. In addition, the actors were also constantly investigating the traits of a person's character, so that it was appropriate to describe the character as either the "white character" or the "black character." Inserts also took place to make reforms or interventions from aspects of speech and treatment. The process of analysing and investigating were conducted by participants in the anti-model play, forum sessions, and intervention play. 


\section{Theme 2: Evaluation Level}

The findings showed that forum theatre can develop thinking skills among the participants, especially at the level of valuing or evaluation. Participants were able to think reasonably and put a moral judgment to the action done by characters in the anti-model play and intervention play. The level of the evaluation was generated by two subthemes, reasoning and judging. The following is an analysis of the findings of the two subthemes that formed Theme 2 .

\section{Reasoning}

The results of the interviews showed that participants were able to reason or make an assessment before composing anti-model acting scripts, considering the appropriate characters for anti-model acting and assessing alternative solutions that should be used in the intervention play. The reviewers considered various factors before generating anti-model play scripts (script D). They were able to consider appropriate issues to describe the theme of respecting women's rights given by their teachers, as noted in the following interview data:

Researcher: Who gives the original idea to compose script D?Participant 5:

We all discussed before writing a script. Everyone has an idea. All of these ideas we consider one by one before writing script $\mathrm{D}$ so that this script is appropriate to describe the theme of human rights or respecting the rights of women given by our teachers.

[school B/int/14.4.18]

\section{Participant 6:}

After acting an anti-model script, we received many comments from Joker and the audience. They also provide many reasons and suggestions for solving the problem of the husband and wife displayed in the antimodel play (script D). We consider all the reasons and alternatives given to be implemented in the intervention play. 
In addition, participants' journal entries also indicated that they had a certain level of thinking, particularly the level of assessment or evaluation. Participants said they would consider the rationale for the action that needed to be taken before composing scripts and acting in the anti-model play and intervention play. Any comments provided in the forum session would also be considered as a solution to the conflicts arising. The following journal entries illustrate this:

Today I was involved in writing a script. In my forum session, there was criticism of Ikhwan's character that he beat his wife (anti-model script D) because his wife did not provide food for the husband who came home from work. I consider this situation to find the best solution to be implemented in the intervention play.

[school B/jur/R2/5.4.18]

Today I acted as a good husband (Ikhwan) in the intervention play. Before that, I also considered the situation of the husband beating his wife. Among the aspects to consider is the cause of the non-cooking wife, the way she treats the husband and the husband is to blame for the wife, and so on. After considering all the factors, I am looking for the best solution. That's why I can play a good husband's role in the intervention play.

[school A/jur/R3/5.4.18]

The observation notes [school B/obs/Ban/18.5.18] showed what participants took into consideration before writing scripts, choosing appropriate characters for anti-model acting, and casting the intervention play. Additionally, the values that must be present in the character, speech and behavioural aspects of the character were also considered for writing the acting dialogue. In a forum session, for example, the Joker provided assessment or evaluation questions to examine the level of thought of the participants. Proposed responses and proposed solutions provided in the forum were assessed by participants before being considered as the absolute solution to be used in the intervention play. It turned out that assessment and judgment aspects were used before implementing and administering script development and forum sessions, and anti-model and intervention play sessions. 


\section{Judge}

The interview results indicated that participants could judge, estimate, or carefully calculate the anti-model play and issues that appeared in the play, and they assessed all proposed solutions submitted in the forum session. After assessing the issues and situations that were appropriate for writing anti-model acting scripts, the participants played the script in the form of an anti-model play and intervention play. The following interviews illustrate this:

Researcher: In a forum session, why are your groups criticizing Esah's character (script E)? Participant 2:

In the anti-model acting, we find that Esah is a negative character that needs to be changed. We made an assessment of the issues that existed in the anti-model play. That's why we criticize the attitude of Esah's character in the forum session. We made a moral judgment that Senah's character should be turned into a positive character in the intervention play.

Researcher: You mentioned the moral judgment. What does this mean? Participant 1:

We mean that, as a viewer we can judge and punish the character acting in the anti-model play. For example, we judge Esah's character as a negative character and needs to be changed in the intervention play. Esah's character is an immoral character...therefore, the attitude of this character needs to be changed to a better character.

[school B/int/14.4.18]

The journal entries of participants also showed that they made judgments based on several criteria through review and criticism, as exemplified by the following journal entry:

Today I was involved in a forum session. In the forum session, I criticized the character of Esah (script E) as an irresponsible character because she likes to make slander against Senah's character. The attitude of Esah's character who loves to slander that Senah has black magic and she uses a bomoh is an immoral attitude. 
Therefore, I propose that the envy of Esah is changed to a more professional attitude.

[school B/jur/R4/15.6.18]

One of the participants also disputed in his journal entry:

I admit Farhan's character attitude (script C) as a son who is not good at honouring parents and maintaining family image. In this anti-model play, I do not like Farhan's character. If I became Farhan's father, I would not forgive Farhan, for he had dropped the family image. Farhan was married to Sara without the parents' knowledge.

[school A/jur/R4/15.6.18]

The observation notes also showed that participants made judgments and assessments about the proposals presented in the forum session. From the notes [school B/obs/Nad/3.4.18], the participants were assessing the issues featured in the anti-model acting and making judgments about the solutions performed in the intervention play session. Attitudes to judging characters' acting in an anti-model session can help them to perform better and perfect their acting in intervention plays. Overall, forum theatre techniques can develop thinking skills. Participants might make judgments before making a decision to resolve an issue.

\section{Theme 3: Creation Level}

Elements such as developing a script, anti-model play and intervention play create an opportunity for participants to be innovative and creative. The results show that forum theatre was able to develop thinking skills, especially the level of creativity among the participants. The creation level theme was generated by two subthemes, planning and generating. The following is an analysis of the findings of the two subthemes that make up Theme 3 .

\section{Planning}

The results of the interview showed that the participants could design the anti-model play's script framework, the situation, the Joker's question, and the intervention play's framework for the script. Before they designed the form of the anti-model script framework, the participants studied the theme provided to find out the needs 
of the theme so that the script created met the means to the theme provided. This is demonstrated in the following interviews:

Researcher: What is the first step in writing antimodel and interventions play scripts? Participant 3:

Our group will plan to get issues that match the theme given. Then we will create a script template that will be composed. Script sketches are important for writing storylines so that they are not out of the theme. Scripture spans are also important to determine the amount of characters needed to play the storyline. We need to design all this before writing an anti-model script.

[school B/int/13.4.18]

\section{Participant 6:}

In addition, planning is also important for us to determine the characters that will act in the anti-model play and intervention play. Character attitudes and dialogue that fit the character attitude should also be considered so that the dialogue can describe the situation to be displayed.

[school A/int/13.4.18]

Journal entries also showed that before the forum session the Joker would design some questions to be presented to the audience as a way to stimulate their thinking. The Joker's questions were probes, which are important to stimulate the idea of an important solution to the conflicts presented in the anti-model play. In addition, participants also planned ways to handle the anti-model and interventions plays, from the number of actors and the number of solutions or ideas that can be put forward in intervention casting. The following journal entries attest to the planning that took place:

Today I was involved in a discussion with my group. As a head, I plan our group's work. We will design agendas and events that must be included in order to fit the theme. Planning for writing an anti-model acting storyline and intervention acting is also carried out by our group. We manage to plan our script and action plan for our play. 
Today I acted as Esah. Esah is one of the characters in the intervention play. Before acting in the intervention play, I was prepared with some strategies such as ways to take over the role of the negative character. I have used such action and dialogue as designed to act it out in the anti-model play. So I can act well in the intervention play.

[school A/Jur/R6/15.3.18]

The observation report [school B/obs/Ban/12.4.18] also showed that participants were planning, almost from the time of writing the anti-model scripts, on how to curb anti-model acting, the number of characters involved, characters capable of describing conflicts in anti-model acting, how to handle forum sessions, and the number of solutions that can be put into intervention casting. These plans are among the most important aspects of creativity.

\section{Generate}

The interview results show that the participants were able to generate acting scripts, anti-model acting, forum session questions, and intervention plays that showed an alternative solution to the problems posed in the anti-model play. The acting script was produced based on a given theme. The following interview data exemplify this:

\section{Participant 6:}

We generate script $\mathrm{E}$ based on the theme of freedom of speech. We need to generate a situation that points to the issue that although there is freedom to speak out, the voice needs to benefit the human being.

Researcher: Can you give us more detail? Participant 5:

We mean that we can show in an anti-model play that, even if we have the right to give an opinion, we cannot use this opportunity to censure, defame or abuse someone. That is why we have a situation in the most problematic business world as a result of jealousy and envy. The attitude of Esah, who likes to make slander, should not be emulated by society. 
The journal entries also showed that participants generated themes to fit the scripts, generated an anti-model play, depicted the conflicts expected in the script, generated situations that fit the given theme, generated forum session questions, generated creative solutions to address issues or conflicts, and rebuilt the storyline and solution that should be played in the intervention casting session. This is apparent in the following journal entries:

Today I was involved in writing the script. For me, forum sessions and anti-model plays can stimulate me to generate ideas for writing scripts, generate situations, anti-model plays, and create acting in intervention plays. I'm happy to give new ideas that can be used and acted in an intervention play...this idea was successful, too.

[school B/jur/R6/25.5.18]

I was told to generate ideas on how to deal with Ikhwan's character problem (script D). Ikhwan's character is a hot-tempered husband. I generated and transformed this character into a positive character in the intervention play. I managed to role-play Ikhwan's character as a husband who understands the wife's heart as an alternative way to the conflict that is featured in the anti-model play.

[school A/jur/R6/25.5.18]

The observation report [school A/obs/Ati/13.6.18] also showed the participants of this study generating anti-model casting, generating characters for anti-model acting, asking for a forum session conducted by the Joker, incorporating ideas submitted in the forum session, and summarizing solutions to resolve conflicts. The participants also restructured negative characters in anti-model acting to play the role as positive characters in the intervention play. This generation aspect has become an important feature of creation and creativity in the mind.

\section{DISCUSSION}

The four steps in the forum theatre stimulate aspects of problem solving and the ability to make judgments before making decisions, and they trigger critical and creative thinking. The participants showed that they were practicing analysing skills whereby they 
managed to break down the information from the anti-model play to understand the moral dilemma involved. They made their stance stronger with justification and evidence from their journal entries and interviews. They used techniques such as investigating, identifying issues, inference, providing justification and speculating to analyse the anti-model play. Their thoughts and opinions were justified and explained in a forum session and when they developed a script. Hence, the evidence above shows that the participants practiced the skills of analysis in their thinking.

Furthermore, it could be seen that all of the students managed to handle and evaluate the good and the bad elements of the characters in the anti-model and intervention plays. Participants could reason or make an assessment before composing anti-model acting scripts, considering the appropriate characters for anti-model acting and assessing alternative solutions that should be used in the intervention play. The participants were able to judge, estimate or carefully calculate issues that appeared in the anti-model play and to assess all proposed solutions submitted in the forum session. After assessing the issues and situations that were appropriate for writing anti-model acting scripts, the participants played the script in the form of an anti-model and intervention play well. Their arguments in the forum session were just, well argued, and had good reasoning that was supported and defended. The participants' ability to defend, argue, counter argue, conclude, and explain was the tool in thinking at the evaluation level.

All the participants managed to create a good moral dilemma script. Participants could design the anti-model play's script framework, the situation, the Joker's question and the intervention play's framework of the script. Before they designed the form of the anti-model script framework, the participants studied the theme provided to find out the needs of the theme so that the script met the means to the theme provided. They were able to generate acting scripts, anti-model acting, forum session questions, and intervention plays that showed an alternative solution to the problem posed in the anti-model play. All of them practiced creation skills whereby they created a script, an anti-model play, and an intervention play to bring the play to a different and improved ending. They justified the play they recreated (intervention play) using details from the values of their society and knowledge of their religion. This shows that HOTS were utilized.

The results of this study are consistent with the findings of Chang (2007) and Colby and Kohlberg (2011) that responses to structured 
situations by students (in the context of this study, the four steps in forum theatre) expand their level of moral judgment and reasoning. Forum theatre is able to develop the aspects of moral thought, thinking skills and reasoning of Form 4 students. This study is also in keeping with the aspirations in the Malaysia Education Blueprint (2013-2025) that students should be creative and innovative so they can generate new possibilities and create new ideas or knowledge to fulfil $21^{\text {st }}$ century needs.

\section{CONCLUSION}

The findings of this study show the potential of forum theatre to promote and develop students' thinking skills on a higher level. With the present urgent need for the mastery of HOTS, teachers need all the help they can get in terms of ideas and resources that will assist them in generating creativity and fun in class. This is what forum theatre offers - engaging activities and the ability to promote HOTS among students. Therefore, this study suggests that forum theatre, with various techniques and elements of the dramatic experience, can be used as moral education pedagogy to enhance HOTS.

This study has shown that forum theatre can develop aspects of thinking skills and the level of thinking among Form 4 moral education students. Forum theatre techniques provide opportunities for students to become aware, to see things critically, to find solutions to moral conflicts, and to develop as prospective citizens with a positive moral attitude. Overall, with this technique students can apply knowledge and thinking skills such analysing, evaluating, creating, reasoning and reflecting to solve problems, make decisions, innovate, and create something (Anderson \& Krathwohl, 2001). The findings of this study reveal that various theatrical activities underpinning the four elements of forum theatre-(i) writing a script, (ii) anti-model play, (iii) forum session and (iv) intervention play - show the development of students' thinking skills such as analysing, evaluating and creating. Therefore, it is clear that forum theatre is able to generate students' HOTS.

\section{ACKNOWLEDGMENT}

We wish to acknowledge the Ministry of Higher Education, Malaysia, the Research Management \& Innovation Centre 
(RMIC) and the Faculty of Human Science, Sultan Idris Education University, Malaysia for the research grant (File No: 2018-0041107-01(GPUBP)) that enabled this study to be carried out.

\section{REFERENCES}

Abdul Pabil, A., Barathi, S., \& Vijayaletcumy, M. (2019). Pendidikan moral Tingkatan 4 (KSSM). Kuala Lumpur: Dewan Bahasa dan Pustaka.

Anderson, L. W., \& Krathwohl, D. R. (Eds.). (2001). A taxonomy for learning, teaching and assessing: A revision of Bloom's taxonomy of educational objectives. New York: AddisonWesley/Longman.

Aravind, C.V., Gamboa, R. A., \& Lim, S. C. (2019). Empowered pedagogy: Catching up with the future. Malaysian Journal of Learning and Instruction, 16(1), 1-22.

Ashton, P. (1988). Teaching higher-order thinking and content: An essential ingredient in teacher preparation. Gainesville: University of Florida Press.

Babbage, F. (2004). Augusto Boal. New York, NY: Routledge.

Balakrishnan, V. (2011). Real-life dilemmas in moral education. Kuala Lumpur: University of Malaya Press.

Balakrishnan, V. (2019). Real-Life Moral Dilemma Discussion (Re-LiMDD) among young adolescents: A comparison between Malaysia and Indonesia. In A. Idris \& N. Kamaruddin (Eds.). ASEAN post-50 (pp.231-238). Singapore: Palgrave Macmillan.

Bloom, B. S. (1956). Taxonomy of educational objectives, Handbook I: The cognitive domain. New York, NY: McKay.

Boal, A. (2008). Theatre of the oppressed (new edition). London, UK: Pluto Press.

Braun, V., \& Clarke, V. (2006). Using thematic analysis in psychology. Qualitative research psychology, 3, 77-101.

Chang, L. H.(June, 2007). Moralreasoning of Malaysian adolescents. Paper presented at the International Conference on Learning, Johannesburg, South Africa.

Colby, A., \& Kohlberg, L. (2011). The measurement of moral judgement (Volume I). Cambridge: Cambridge University Press.

Dewey, J. (1909). Moral principles in education. Carbondale, IL: Southern Illinois University Press. 
Fisher, R. (2003). Teaching thinking. London, UK: Continuum.

Gourd, K. M., \& Gourd, T. Y. (2011). Enacting democracy: Using forum theatre to confront bullying. Equity \& Excellence in Education, 44(3), 403-419.

Hanita, M. Y., \& Norzaini, A. (2018). Academic achievement among male and female students: The role of learning support and students' engagement. Malaysian Journal of Learning and Instruction, 15(2), 257-287.

Jeevajothi, N. (1997). Keberkesanan perbincangan dilema moral dalam perubahan peringkat moral di kalangan pelajar tingkatan empat (Unpublished master's dissertation). Universiti Malaya, Malaysia.

Kaviza, M. (2020). Motivasi intrinsik dan kemahiran berfikir kritis dalam pembelajaran sejarah berasaskan analisis sumbersumber teks: Satu kajian faktorial. Jurnal Pendidikan Bitara, 13(1), 17-26.

Kohlberg, L. (1984). The psychology of moral development. San Francisco, CA: Harper \& Row.

Kristjansson, K. (2009). Putting emotion into the self: A response to the 2008 journal of moral education, special issue on moral functioning. Journal of Moral Education, 38(3), 255-270.

Letchumie Devi, V. R., \& Nadarajan, T. (2020). Caring moral reasoning through forum theatre in teaching and learning of moral education. Muallim Journal of Social Sciences and Humanities, 4(2), 214-228.

Levy, J. (1997). Theatre and moral education. Journal of Aesthetic Education, 31, 65-75.

Ministry of Education Malaysia. (2000). Moral education syllabus for secondary school, Malaysia. Kuala Lumpur: Curriculum Development Centre.

Ministry of Education Malaysia (2013). Malaysia education blueprint 2013-2025 (Preschool to post-secondary education). Putrajaya: Author.

McClimens, A., \& Scott, R. (2007). Lights, camera, education! The potentials of forum theatre in a learning disability nursing program. Nurse Education Today, 27(3), 203-209.

Mohd Zaidi, H. M. Z., Ahmad Zabidi, A. R., \& Rafiza, A. R. (2020). Cabaran pengajaran guru pendidikan Islam di sekolah pedalaman: Bersediakah dalam melaksanakan KBAT? Jurnal Kurikulum \& Pengajaran Asia Pasifik, 8(1), 11-24.

Mohd Zailani, M. Y. (2012). Faktor-faktor penyumbang dalam pertimbangan moral pelajar sekolah agama. Malaysian Journal of Learning and Instruction, 9, 81-109. 
Nadarajan, T. (2019). Potensi unsur-unsur teater forum dalam pembentukkan insan menyeluruh: Dapatan kajian kualitatif kelas pendidikan moral. Muallim Journal of Social Sciences and Humanities, 3(1), 77-95.

Nadarajan, T., Harun Joko Prayitno., \& Gamal Abdul Nasir, Z. (2020). Incorporating active learning into moral education to develop multiple intelligences: A qualitative approach. Indonesian Journal on Learning and Advanced Education (IJOLAE), 3(1), 17-29.

Narvaez, D., \& Lapsley, D. K. (2008). Teaching moral character: Two strategies for teacher education. The Teacher Educator, 43(2), 156-172. https://doi:10.1080/08878730701838983

Norhezan, C. T., Nor Hashimah, I., \& Ainon, O. (2017). Critical thinking module in promoting higher order thinking skills among secondary school students. The Asian Journal of English Language \& Pedagogy, 5, 68-79.

Norzihani, S., \& Nur Surayyah Madhubala, A. (2015). Elemen dalam program penyediaan guru sebagai pemudah cara pemikiran moral guru pelatih Pendidikan Moral. Jurnal Kurikulum \& Pengajaran Asia Pasifik, 3(2), 1-13.

Passi, B. K., \& Mishra, S. (2002). Selecting research areas and research design approaches in distances education, Process Issues, 5(3), 1-11.

Rajendran, N. S. (2017). Pengajaran dan penguasaan kemahiran berfikir aras tinggi: Teori \& amalan. Tanjong Malim: Penerbit Universiti Pendidikan Sultan Idris.

Richards, L., \& Morse, J. M. (2007). Readme first for a user's guide to qualitative methods. London: Sage.

Schonmann, S. (2005). "Master" versus "servant": Contradictions in drama and theatre education. Journal of Aesthetic Education, 39(4), 31-39.

Suppiah, N., Barathy, S., \& Sandra, S. (2017). Masalah dalam pengajaran dan pembelajaran pendidikan moral di sekolah menengah dan penyelesaian masalah melalui kaedah hermeneutik. Journal of Research, Policy \& Practice of Teachers \& Teacher Education, 7(2), 58-68.

Tajularipin, S., Vickneswary, M., Diwiyah, M., Raidah, H., \& Suzieleez Syrene, A. R. (2017). Implementation of higher order thinking skills in teaching of sciences: A case study in Malaysia. International Research Journal of Education and Sciences, 1(1), 1-3. 
Varutharaju, E., \& Ratnavadivel, N. (2014). Enhancing higher order thinking skills through clinical simulation. Malaysian Journal of Learning and Instruction, 11, 75-100. 